\title{
Design Clinical Decision Support System (CDSS) in Electronic Health Record to Early Detection of Stroke Disease, Diabetes Mellitus and to Prevent Interaction of Drug Content
}

\author{
Feby Erawantini ${ }^{1, *}$, Arinda Lironika Suryana ${ }^{2}$, Rinda Nurul Karimah ${ }^{3}$, Arief \\ Setyoargo ${ }^{4}$ Nachrul Jinan ${ }^{5}$, Khoirunnisa Afandi ${ }^{6}$, Nugroho Setyo Wibowo ${ }^{7}$, Asmak \\ Afriliana $^{8}$, Raden Roro Lia Chairina ${ }^{9}$ \\ 1,2,3, Department of Health, Politeknik Negeri Jember, Indonesia \\ ${ }^{4}$ Department of Education and Research, RSUD dr. Soebandi Jember, Indonesia \\ ${ }^{5}$ Department of Medical Record, RSUD dr. R. Soedarsono, Indonesia \\ ${ }^{6}$ Department of Information Technology, Institut Teknologi Sepuluh Nopember, Indonesia \\ ${ }^{7}$ Department of Information Technology, Politeknik Negeri Jember, Indonesia \\ ${ }^{8}$ Department of Food Science,' Universitas Jember, Indonesia \\ ${ }^{9}$ Department of Agribusiness Management, Politeknik Negeri Jember, Indonesia \\ "Corresponding author. Email: feby erawantini@polije.ac.id
}

\begin{abstract}
Hospitals must provide the best service to patients. There are include speed in service, on-time, and safe from medical errors. Quality of care depends on quality electronic medical records. Electronic medical records contain social data and patient medical data. The advantages of medical records are data stored in structured files, and timely filling, data can be recalled at any time, ensures patient confidentiality, and ensures patient safety. One of the indicators of electronic health records is clinical decision support systems (CDSS). This study aims to design a clinical decision support system (CDSS) in Electronic Health Records for early detection of stroke disease and to prevent interaction drug content. The method Methode for System Development used Waterfall and System Requirements Analysis was analysed by qualitative. The results of this research are to design a clinical decision support system (CDSS) in Electronic Health Records to early detection of stroke disease and to prevent interaction drug content.
\end{abstract}

Keywords: Design, Clinical Decision Support System, Electronic Health Record

\section{INTRODUCTION}

The community has the right to obtain quality and affordable health services[1]. The quality of health services is a step towards improving health services both for individuals and for the population in accordance with the expected health outcomes for the latest professional knowledge [2]. The provision of health services must reflect the accuracy of the use of knowledge so that the services provided are truly appropriate and can ensure patient safety.

The use of resources and activities that are very complex in hospitals or clinics have the potential for errors, such as misdiagnosis, prescribing more than standard or excessive doses that result in serious or fatal consequences for patients [3]. According to the House Of Commons Health Committee Patient Safety Sixth Report of Session 2008-09 Volume I stated that in London $10 \%$ of patients hospitalized suffered enormous damage and some of this damage could have been avoided, tens of thousands of patients suffered enormous losses every year [4]. Previous findings report IOM (Institute for Medicine's) in 1999, The data showed that due to 'Medical errors' reached 98,000 people, losses were between \$17-29 Million and the largest contributor was 'Medical errors'[5]. In Indonesia, the data about medical errors has not been found. Some hospitals still use manual medical records, therefore there is a chance of misfiling and incomplete. In Mitra 
Medika Medan Hospital shows misfile of $6 \%$ of medical records [6]. The other article shows there were $70 \%$ causative misfile factors (such as; education, age, and length of work) from medical record operators [7]. The implementation of electronic health records with CDS is expected to prevent misfiles, provide complete data and improve patient safety.

The objectives of this research were to design a Clinical Decision Support System (CDSS) in Electronic Health Records for early detection of stroke disease and preventing the interaction of drug content.

\section{METHOD}

This research had been carried out at RSUD dr. Soebandi Jember in Januari until Oktober 2021. Methode for System Development used Waterfall and System Requirements Analysis was analysed by qualitative. Respondents of this research were 2 Neurologists, 2 Internists, Deputy Director of Health Services of dr.Soebandi General Hospital.

Researchers and team observed all forms that were used for recording data patients, especially in the outpatient department. After that, we designed usescase diagram, Flow Chart, Data Flow Diagram (DFD), and Entity Relationship Diagram (ERD) based on the respondent's need. The design had been presented to the respondent to get feedback from them.

\section{RESULTS AND DISCUSSION}

\subsection{User Requirements}

The neurologists explained that there are two types of stoke, stroke hemorrhagic and Ischemic. This table shows stroke risk factor mapping.

Table 1. Stroke Risk Factors Mapping

\begin{tabular}{|c|c|c|c|}
\hline Divuu riesuie & $>140 / 70$ & 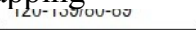 & $\because I \angle U / O U$ \\
\hline Atrila Fibrillation & Irreguler Pulsed Rate & Pilse is not palpable & Reguler pulse rate \\
\hline Smoking habit & smoker & Occasionally smoker & Nit smoker \\
\hline Cholesterol & $>240$ & $200-239$ & $<200$ \\
\hline Diabetes & Yes & There is family history & No \\
\hline Physical activity & Infrequent & Occasional & Frequent \\
\hline Body weight & Overweight & Slightly overweight & Normal \\
\hline Family history with stroke & Yes & Not sure & No \\
\hline
\end{tabular}

[8]

The design CDSS was done by mapping the risk factors and stroke symptoms in the patients, then the inference mechanism was made to allow early detection in patients with risk of stroke. The mechanism of inference was made through discussion activities with experts. The design results that have been appropriate or accepted can be used operationally.
Internist said :

\section{"Diabetes mellitus is a multifactorial disease of considerable heterogeneity"}

Risk factors of diabetes mellitus are overweight, hypertension, rarely exercising, and having a history of family member's with Diabetes Mellitus. There are so many factors of DMT2. Overweight, Hypertension, performing regular physical activities, high cholesterol and so on [9].

$$
\text { ".....please made a system that easy to use" }
$$

The design is based on the risk factors DMT2 to create an algorithm of risk factors DMT2. Basically, stroke and diabetes are related. Diabetes is a risk factor for stroke. Obese, hypertension, high cholesterol, rarely exercise are possible to suffer from both stroke and diabetes.

\subsection{Usecase Diagram}

Use case diagrams are used to gather the requirements of a system including internal and external influences [10]. Figure 1 was drawn based on observations of activities in the outpatient in Subandi General Hospital.

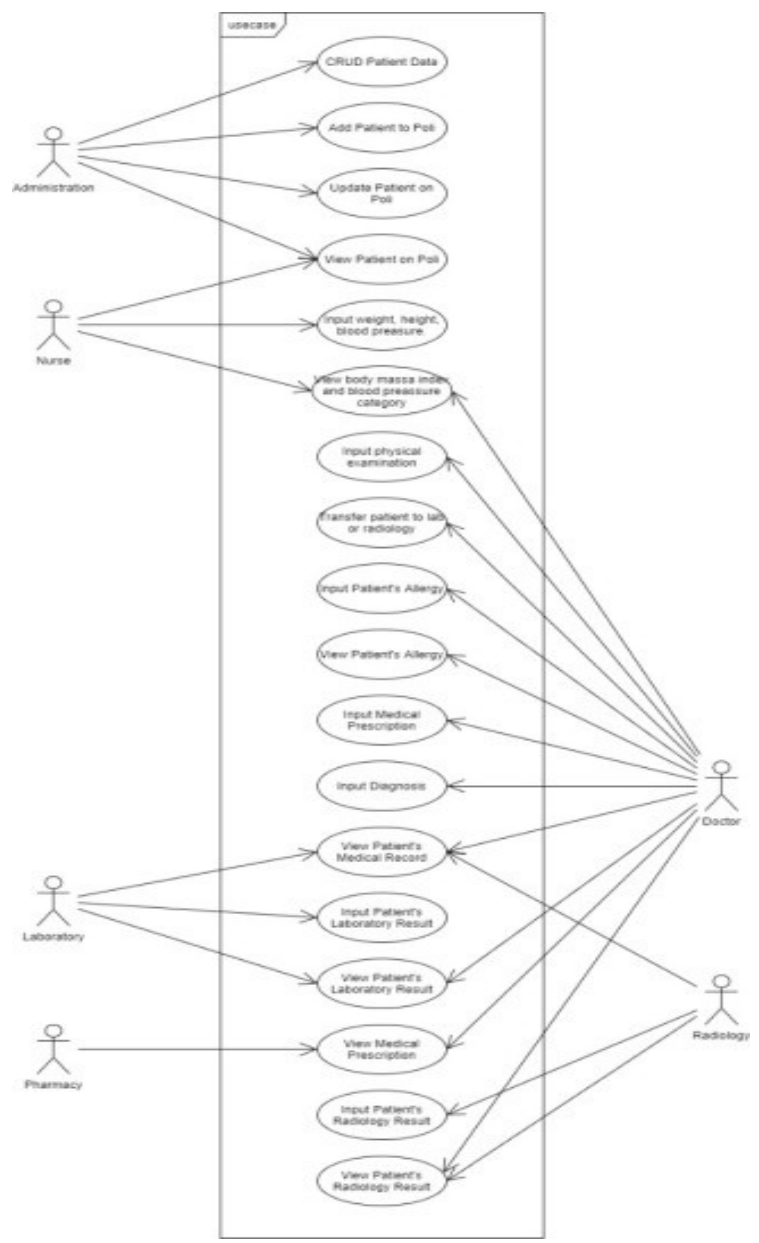

Figure 1 Usecase Diagram of Electronic Health Record 
There were 5 actors integrated into the system. They were administrative staff, nurses, doctors, pharmacists, Laborant, and Radiologist.

\subsection{Flowchart}

Flowcharts have been used to represent the conceptual structure of complex software systems. In many of the literature on software development, the flowchart serves as the central design document around which systems analysts, computer programmers, and end-users communicate, negotiate, and represent complexity. And yet the meaning of any particular flowchart was often highly contested, and the apparent specificity of such design documents rarely reflected reality[11].

Figure 2 is a flowchart that shows the Clinical Decision Support System of the risk factor of Stroke, DMT2 and drug content reaction.

Risk factors were drawn in Figure 2. There were body mass index (BMI), blood pressure, family history of stroke, and family history of stroke.

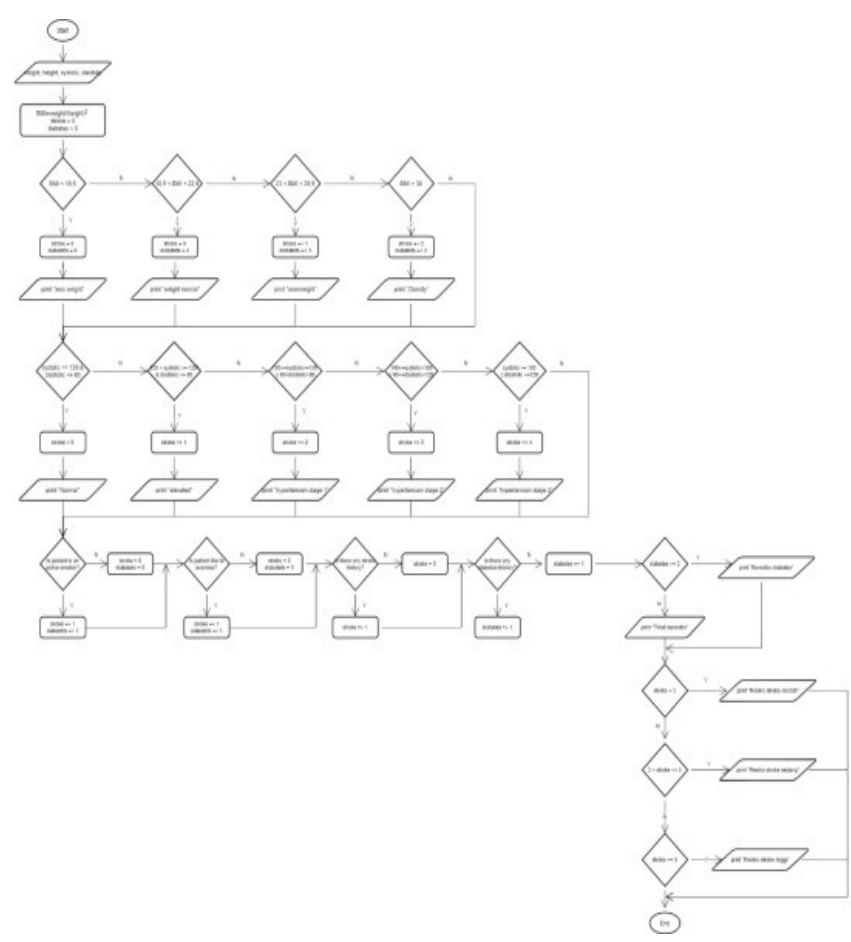

Figure 2 flow Chart of Electronic Health Record

\subsection{DFD (Data Flow Diagram)}

DFD are the cornerstones for structured system analysis and design, which is considered a document that can be shown to analysts and designers [12].
The admission office has to enter social data patients into the system. The nurse could show, and input social data patient, physical examination data to the system. The radiology and laboratory office received requests from the doctor and then sent the result back to the doctor. The doctor has to check laboratory, and radiology data. After that doctor could input diagnosis to the system based on data patient, radiology, and laboratory data. Doctor order medical prescription that could be read by Pharmacy.

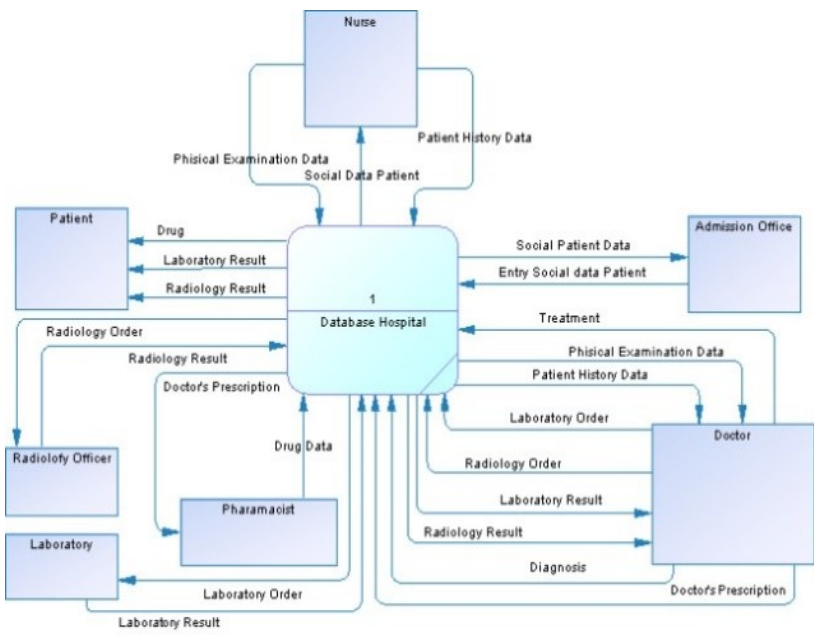

Figure 3 DFD of Electronic Health Record

\subsection{ERD (Entity Relationship Diagram)}

The Entity-Relationship diagram has been widely used in structured analysis and conceptual modelling. The ERD approach is easy to understand, powerful to model real-world problems and readily translated into a database schema [13]. ERD shows the Tables of Electronic Health Record. There are Master Tables and Transactional Tables.

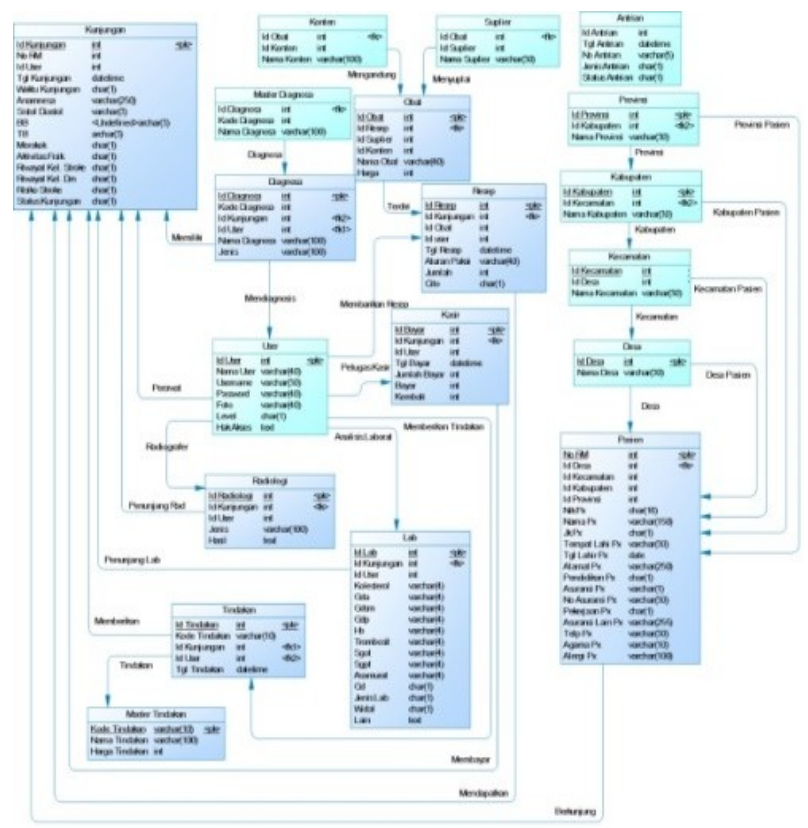


Figure 4 ERD of Electronic Health Record

\section{CONCLUSION}

Design Clinical Decision Support System (CDSS) in Electronic Health Record to Early Detection of Stroke Disease and to Prevent Interaction of Drug Content start by interviewing the user, designing of Flow Chart, DFD, and ERD. This design can improve the quality of service and patient safety in hospitals because it can support medical records that are more integrated.

\section{AUTHORS' CONTRIBUTIONS}

All authors contribute to the research design and implementation, result analysis, and text writing.

\section{ACKNOWLEDGMENTS}

The authors thank the Ministry of Education, Culture, Research and Technology of The Republic of Indonesia for the financial support of the research.

\section{REFERENCES}

[1] I. Hadiyati, N. Sekarwana, D. K. Sunjaya, and E. P. Setiawati, "Konsep Kualitas Pelayanan Kesehatan berdasar atas Ekspektasi Peserta Jaminan Kesehatan Nasional Health Service Quality Concept based on Expectation of the National Health Insurance Participants," vol. 49, no. 2, 2017.

[2] E. Stefani, "Tinjauan Yuridis Pelayanan Kesehatan Yang Bermutu Menurut Pasal 5 Ayat (2) Undang-Undang Nomor 36 Tahun 2009 Berkaitan Dengan Kekecewaan Pasien Terhadap Perilaku Dokter," no. 2. Universitas Atma Jaya Yogyakarta, Yogyakarta, pp. 561-565, 2014.

[3] Dublin, "Building a Culture of Patient Safety Patient Safety Report Of The Commission On," Ireland, 2008.

[4] H. of Commons, "Patient Safety Sixth Report of Session 2008-09," London, 2009.

[5] S. Bleich, "Issue Brief Medical Errors: Five Years After the IOM Report," Health Policy (New. York)., 2005.

[6] Esraida Simanjuntak dan Lisna Wati Oktavin Sirait, "Bagian Penyimpanan Berkas Rekam Medis Rumah Sakit Mitra Medika Medan Tahun 2017," J. Ilm. perekam dan Inf. Kesehat. IMELDA, no. 1, pp. 370-379, 2018, [Online]. Available:

https://media.neliti.com/media/publications/299 192-faktor-faktor-penyebab-terjadinya-missfiaf5f745c.pdf.
[7] W. A. Putri and W. A. Putri, "Faktor Penyebab Missfile Pada Berkas Rekam Medis di Rumah Sakit," J. Manaj. Inf. Kesehat. Indones., vol. 7, no. $2, \quad$ p. $140, \quad 2019$, doi: 10.33560/jmiki.v7i2.232.

[8] F. Erawantini and R. N. Karimah, "Early Warning Systems (E-Wars) Design for Early Detection of Stroke Incidence," Folia Medica Indones., vol. 54, no. 2, p. 136, 2018, doi: 10.20473/fmi.v54i2.8864.

[9] M. A. Al Mansour, "The prevalence and risk factors of type 2 diabetes mellitus (DMT2) in a semi-urban Saudi population," Int. J. Environ. Res. Public Health, vol. 17, no. 1, pp. 1-8, 2020, doi: 10.3390/ijerph17010007.

[10] Mule, "ROLE OF USE CASE DIAGRAM IN S/W DEVELOPMENT," Int. J. Manag. Econ., 2015, [Online]. Available: https://www.researchgate.net/publication/32299 1847_role_of_use_case_diagram_in_software_d evelopment/link/5a7b38b9aca27233575a83ae/ download.

[11] N. Ensmenger, "The Multiple Meanings of a Flowchart," Inf. Cult., vol. 51, no. 3, pp. 321351, 2016, doi: 10.7560/ic51302.

[12] A. Asakr and D. T. Mosab, "Data Flow Diagrams of an Electronic Medical Record System in Mansoura Hospital," Int. J. Comput. Technol., vol. 15, no. 7, pp. 6885-6897, 2016, doi: $10.24297 /$ ijct.v15i7.1532.

[13] A. A.-S. Al-Btoush, "Extracting Entity Relationship Diagram (ERD) From English Sentences," Int. J. Database Theory Appl., vol. 8, no. 2, pp. 235-244, 2015, doi: 10.14257/ijdta.2015.8.2.22. 